IRSTI 03.41 .91

Tishkin A.A. ${ }^{1}$, Besetayev B.B. ${ }^{2}$

${ }^{1}$ Doctor of Historical Sciences, Professor, Altai State University, Russia, Barnaul, e-mail: tishkin210@mail.ru

${ }^{2}$ Doctoral Candidate, al-Farabi Kazakh National University,

Kazakhstan, Almaty, e-mail: besetaev86@mail.ru

\title{
TO THE STUDY OF THE SADDLE-HORSE HARNESS FROM THE SAKA TIME ON THE TERRITORY OF KAZAKHSTAN
}

Studying the horse harness of the early nomads of Kazakhstan is currently an urgent task, the solution of which will complement the characterization of the culture of the Saka-Scythian time. This article is devoted to the history of studying the complex of horse harness of the Scythian-Saka era. Common cultural and chronological definitions are used. The chronological framework of the study includes a transition period from bronze to iron (IX-VIII centuries BC), the Early Saka time (VIII-VI centuries BC), Saka (VI-IV centuries BC) and the final stage of the Pazyryk culture (IV-III centuries BC), which determines the ethnic connection and intercultural relations of tribes with adjacent regions. This period is characterized by the dynamic variability of horse harness. In general, details of horse harness are widely used in the construction of chronological scales, the reconstruction of migration processes in antiquity, etc. Detailed study and various analyzes of horse harnesses will help solve common and particular problems of archaeology of the Saka-Scythian time.

Key words: Kazakhstan, Saka-Scythian time, early nomads, harness of the horse.

Тишкин А.А. ${ }^{1}$, Бесетаев Б.Б. ${ }^{2}$

${ }^{1}$ тарих ғылымдарының докторы, профессор, А^тай мемлекеттік университеті, Ресей, Барнаул қ., e-mail: tishkin210@mail.ru

${ }^{2}$ Аокторант, әл-Фараби атындағы Қазақ, ұлттық, университеті, Қазақстан, Алматы қ., e-mail: besetaev86@mail.ru

Қазақстан территориясындағы сақ кезеңіндегі ат әбзелдерінің зерттелуі

Бүгінгі таңда Қазақстан территориясындағы ерте көшпелілердің ат әбзелдерін зерттеу сақ-скиф кезеңінің мәдениетінен мәлімет беретін өзекті мәселелердің бірі болып табылады. Мақалада жалпы ортақ, мәдени-хронологиялық негіздеріне сүйене отырып, сақ-скиф кезеңінің ат әбзелдерінің зерттелуі қарастырылған. Зерттеу жұмысының хронологиялық шеңбері көшпелі сақ, тайпаларының көршілес аймақтармен өзара мәдени қарым-қатынас пен этникалық, туыстастық, мәселелерін анықтайтын соңғы қола дәуірінен ерте темір дәуіріне өтпелі кезең (б.з.А. IX-VIII ғғ.), ерте сақ кезеңі (б.з.А. VIII-VI ғғ.), сақ кезеңі (б.з.А. VI-IV ғғ.) және пазырық мәдениетінің соңғы кезеңі (б.з.А. IV-III ғғ.) аралығын қамтиды. Аталмыш кезең ат әбзелдердің динамикалық, дамуымен ерекшеленеді. Негізінен, ат әбзелдерінің бөліктері хронологиялық мерзімдеу, ежелгі көші-қон үлерістерін қайта қалпына келтіруде және т.б. кеңінен қолданылады. Ат әбзелдерінің бөлшектерін жүйелі түрде зерттеу және әртүрлі сараптама жасау сақ-скиф кезеңінің археологиясына қатысты жалпы және жекелеген мәселелерді шешуге жол ашады.

Түйін сөздер: Қазақстан, сақ-скиф кезеңі, ерте көшпелілер, ат әбзелдер. 


\title{
Тишкин А.А. ${ }^{1}$, Бесетаев Б.Б. ${ }^{2}$ \\ ${ }^{1}$ Аоктор исторических наук, профессор, А^тайский государственный университет, Россия, г. Барнаул, e-mail: tishkin210@mail.ru ${ }^{2}$ Аокторант, Казахский национальный университет имени аль-Фараби, Казахстан, г. Алматы, e-mail: besetaev86@mail.ru \\ Изучение снаряжения верхового коня сакского времени на территории Казахстана
}

\begin{abstract}
Изучение конского снаряжения ранних кочевников Казахстана в настоящее время является актуальной задачей, решение которой, в свою очередь, дополнит характеристику культуры сакоскифского времени. В Аанной статье рассматривается история изучения комплекса конского снаряжения скифо-сакской эпохи. Используются общепринятые культурно-хронологические определения. Хронологические рамки исследования включают в себя переходный период от бронзы к железу (IX-VIII вв. Ао н.э.), раннесакское время (VIII-VI вв. Ао н.э.), сакское (VIIV вв. Ао н.э.) и завершающий этап пазырыкской культуры (IV-III вв. Ао н. э.), что определяет этническую связь и межкультурные взаимоотношения племен с сопредельными регионами. Указанный период характеризуется динамической вариативностью конского снаряжения. В целом, детали конского убранства широко используются в построении хронологических шка^, реконструкции миграционных процессов в древности и т.А. Аетальное изучение и различные анализы предметов конской упряжи помогут решению общих и частных проблем археологии сако-скифского времени.
\end{abstract}

Ключевые слова: Казахстан, сако-скифское время, ранние кочевники, снаряжение верхового коня.

\section{Introduction}

It is well known that the era of the early nomads in Kazakhstan includes the change of two chronic periods (Early Saka time -9 th -6 th centuries BC and Saka time -5 th -3 th centuries BC). Peripherals of nomadic culture The Kazakh level in relation to the sedentary agricultural society contributed to the formation of a distinctive archaeological cultural here with its specific economic structure. Despite certain differences, in the archaeological cultures of the mountain-steppe Kazakhstan in the early Iron Age appeared a whole complex of objects, demonstrating their unity. One of the key components of the «Scythian triad» - riding horse harness (Olkhovsky, 1997: 85) is an important element in the traditional culture of Saka tribes, the study of which is currently an urgent task, the solution of which, in turn, will complement the characteristics of the culture of the early nomads.

The Saka era in the steppe and mountainsteppe regions of Kazakhstan is characterized by a distinct dynamism of horse harness, which largely determines the structural cyclist in the development of cultures, the study of which is important for understanding the origins and ways of forming the Saka-Scythian-Siberian world in general. Complexes with horse harness, fixed in Saka monuments, are often used for relative chronological reference of the latter on the basis of the typological method. Due to their specificity, these products throughout the Scythian-Saka era were constantly improved and subjected to modernization, which makes it possible to trace in time the process of changing their appearance and functioning features (Besetaev, 2015: 26-27).

We consider it important to note that chronologically and geographically the harness of the horse of the Saka tribes is represented unevenly. In the central and southern regions of Kazakhstan, almost exclusively Early Saka harness of the 7th early 6 th $\mathrm{c}$. BC. In some cases, dated $5^{\text {th }} \mathrm{c}$. BC. In East Kazakhstan, the situation is different, but we will return on this later. Nevertheless, we will try to make a historiography analysis of the study of horse harness of the tribes of the Saka range.

\section{Discussion}

In the historiography aspect, the study of horse harness begins from 20-30 years XX century. M.P. Gryaznov, based on field materials A.V. Adrianov (excavated in 1911, the Mayemer burial ground near the modern village of Soldatovo, Katon-Karagai district of East Kazakhstan), created a reconstruction of the reins and harness of the horse of the Early Scythian and Pazyryk times, identified characteristic features of this region for horse harness (Gryaznov, 1947: 10). After researching M.P. Gryaznov of the royal kurgan Arzhan I, with 160 burials of trooped horses, it became clear that horse harness is the most informative and important source in studying 
the culture of the early nomads (Gryaznov, Mannayool, 1973: 208-209; Gryaznov, 1980: 7).

Details of horse harness are among the most massive finds, as burials in accordance with the ritual of a trooper with a horse are a characteristic feature of the funerary monuments of the nomads of the Scythian and Saka time of East Kazakhstan. Items of horse harness are the most significant for determining the chronology of monuments of the early Scythian time. To date, the most studied monuments of nomadic nobility. The presence of both common and specific features in the «royal» kurgans of the Pazyryk culture was noticed by S.I. Rudenko. When comparing the 2nd Bashadar and Pazyryk kurgans, it distinguishes differences in the location of horse harness in graves (Rudenko, 1953: 164-167, 344345).

From 1935 to 1971, complex archaeological research was conducted in the territory of East Kazakhstan, under the direction of S.S. Chernikov, who formulated the general picture of the «Scythian world» in this territory. S.S. Chernikov, according to the chronological framework, divided the monuments of the Scythian period of Eastern Kazakhstan into two stages. The first (VII-IVth centuries BC) is characterized by large rich kurgans (Shilikty valley, Mayemer, Berel, etc.), the domination of bronze tools and weapons (daggers, knives, arrowheads, elements of horse harness of characteristic forms), art - magnificent examples of animal style. Two ethnographic groups are clearly divided - the southern one, associated with the Saka tribal union and the northern one, which included the population that left the mounds of the Pazyryk group. The second stage (III-I centuries BC) includes monuments of Kulazhorga type (Chernikov, 1968: 63).

In 1959, a special scientific interest in the monuments of the early nomads of East Kazakhstan was shown by S.S. Sorokin, resuming the excavations of the last century (Sorokin, 1962: 70). Among the numerous monuments (Katon, Mayemer, Soldatovo, Solonechny belok, etc.), investigated by S.S. Sorokin in the territory of East Kazakhstan, the most important is the Kurt II burial ground. Ss Comparing the inventory from this repository with materials from the Bolsherechensk and Mayemer stages, Sorokin noted the differences between them. Thus, the burial of a person in a crouched position and with a horse that was also buried from the Kurtu II burial ground S.S. Sorokin referred to the time of the earlier one, having for the first time grown the chronology of early nomadic monuments before the 9th century BC (Sorokin, 1966: 45,). Later, L.S. Marsadolov, studying psalm from Altai VIII-VII centuries $\mathrm{BC}$, took the finds of horse harness from the Kurt II burial ground to the arzhan-chernogor group, along with finds of horse harness from the royal kurgan Arzhan (Marsadolov, 1998: 6-7). Unfortunately, today the early stage (Kurtu-Mayemer) is little studied.

The first analytical work on horse harness Saka time is the work of M.K. Kadyrbaev, on Tasmola culture of Central Kazakhstan (Kadyrbaev, 1966: 383-388). M.K. Kadyrbaev made a typology of details of horse harness of Saka tribes. The author analyzed 23 pairs of gag-bits, of which 13 came from random finds, and 10 from excavations, and 6 psalms. M.K. Kadyrbaev singled out 4 types of bits: 1) with asymmetrical endings and an additional hole; 2) with a fast ending; 3 ) with a fast-rectangular end; 4) ringed. According to M.K. Kadyrbaev, the earliest types are aspirated endings with an additional hole. However, noting that on the territory of Kazakhstan I and II types are found in the same types of burials, the lower limit of which can be attributed to the VII century. BC. The appearance of ringed gag-bits, according to M.K. Kadyrbaev, can refer to the time of the second half of the VI BC. Of the 6 found psalms M.K. Kadyrbaev singled out 5 types: 1) horny or bronze three-holed; double-hooked; 3) three-holed with a central hole perpendicular to the side; 4) three-looped; 5) iron with gold inlay. Other details of horse harness were also considered - pierced, warts, pommel, plaques (Kadyrbaev, 1966: 303-433). Later, in 1968, M.K. Kadyrbayev attracting new materials, clarifies the chronology of aspirated fish with an additional hole and refers them to the beginning of the VIII century BC (Kadyrbaev, 1968: 31).

Remarkable finds of horse harness were found in the Saka burial grounds of Uigarak and South Tagisken. In the work of O.A. Vishnevskaya and M.A. Itina proposed a general chronological classification of riding horse harness (Vishnevskaya, Itina, 1971: 201-203). According to the authors, the earlier are considered to be three-horny horny hymns and aspirate bits. When clarifying the chronology, the authors refer to the materials of the Tasmola V burial mound 2 and Tasmola I kurgan 1. According to N.G. Gorbunova, there are some differences between the Tasmola and the Aral Sea (Gorbunova, 2001: 181). In the 2 barrow of Tasmola $\mathrm{V}$, the psalm is slightly curved, the holes are equally equidistant. And in the 14 mound Tagisken also slightly curved horny psalm has a large central hole. The chronological framework of the line proposed by O.A. Vishnevskaya and M.A. Itina VII-VI centuries $\mathrm{BC}$, except for the single-winged ones from 
Uigarak, dated by the authors of the Vth century BC (Vishnevskaya, Itina, 1971: 208), which was mentioned above.

Later, O.A. Vishnevskaya, examining the horse harness from the fifteen graves of the Uigarak burial ground, notes the similarity in the forms of fished, psalm, and methods of their combination. It also suggests a gradual improvement in aspirated gag-bits, which repeat the form of soft gag-bits (Vishnevskaya, 1973: 103).

The most interesting bronze details of horse harness were published by K.A. Akishev and A.K. Akishev, found on the left bank of the river Bizhe (Akishev, Akishev, 1978: 38-40). The set includes incoming and outgoing elements (Bizhe 1 and Bizhe 2 ), as well as ten narrow distribution devices with narrow and vertical suspensions. Two tops, adorned with goat's heads, have traces of harmony from the belts in the rings, which was one of the reasons for interpreting the top as details of horse harness. Analyzing bridle details with Eastern European materials, the authors note that aspirated bits are used already in the pre-Scythian time, with an additional hole in the early Scythian time (VIII-VII centuries BC). Having considered a lot of similar details of horse harness, the authors find analogies from South Tagisken and Uigarak, and date the treasure of the 8th-7th centuries BC (Akishev, Akishev, 1978: 47-48).

A significant contribution to the study of archaeological monuments of the early nomads of East Kazakhstan was made by F.Kh. Arslanova. In the course of targeted reconnaissance in the Upper Irtysh, she identified and explored a number of new monuments belonging to different eras - from the late Bronze Age to the Iron Age and the middle Ages. Also of great importance were the articles of F.Kh. Arslanova dedicated to the late Andronov burials, monuments of transitional time from bronze to the Iron Age (IX-VIII centuries BC), and early Saka complexes of the VII-VI centuries BC, found in the burial grounds near the villages of Kamyshinka and Chistyi Yar. Analysis of analogies to things from the early Scythian cemeteries allowed us to trace the uniformity of the forms gag-bits, psalms, and other bronze elements of horse decoration in synchronous monuments of Kazakhstan (Arslanova, 1972: 254). Based on this, F.Kh. Arslanova comes to a common opinion with N.L. Chlenova, who developed the general typological scheme of the Tagar horse harness of the 7 th -5 th centuries $\mathrm{BC}$, which in her opinion, originates from the territory of modern Kazakhstan.

In the course of her reasoning, she raises the question of the origin of the Early Scythian horse harness, substantiates his chronology and continuity from the decoration of the horse of the Late Bronze Age (Chlenova, 1967: 81).

Thus, the materials from these complexes allowed the researcher to restore the appearance of the culture of that time in the Upper Irtysh. Also determine the proximity of this culture to the Mayemer monuments of Altai and Tasmola kurgans of Central Kazakhstan. In this connection, the opinion of S.I. Rudenko, those pastoral tribes came to Mountain Altai with a fully developed culture from the southwestern steppes around the beginning of the 7th century BC (Rudenko, 1960: 201).

Quite interesting is the random discovery of bronze items found near the village of Ushbiik, Zharma district, published by F.Kh. Arslanova in 1981 the complex includes items of horse harness and arrowheads. Duplex bronze psalm were threaded into the outer bronze oval rings, the ends of which were decorated as gryphon heads. Among the bronze things there were other details of the bridle and saddle complex that retained the features of the early Saka time, dated by the author of the 5th century BC (Arslanova, 1981: 54-55).

Investigations in the future reservoir zone of the Shulbinsk Hydroelectric Power Station on the Irtysh, located on the border of the Semipalatinsk and East Kazakhstan regions, were essentially a continuation of previous studies and also had the main purpose of saving the archaeological monuments of the Upper Irtysh River. After exploration in 1977 of the Shulbinsk archaeological expedition of the Institute of History, Archaeology and Ethnography named after Sh.Sh. Valikhanov of the Academy of Sciences of the Kazakh SSR in 1980-1983 stationary works were performed on monuments that fell into the flood zone of the Shulbinsk Hydroelectric Power Station. In 1977, 1980, 1982 the expedition was led by A.G. Maximova, in 1981, 1983 - C.M. Akhinzhanov. In different years, archaeologists F.Kh. Arslanova, A.S. Zagorodniy, N.A. Bokovenko, L.N. Ermolenko et al. The results of the research activity were soon reflected in the work «Archaeological Monuments in the Flooded Area of the Shulbinsk Hydroelectric Power Plant». Excavations by A.S. Yermolayeva at the Izmaylov burial ground was shown exponential finds gag-bits and psalms, among the things with aspirate bits were two- and three-haired bronze hymns. Three holes were shifted to the center of the product, and the double-leaved psalm imitated the shape of horny items with the loss of the central hole. The monument is dated in the framework of the IX - VII centuries BC (Yermolaeva, 1987: 
135-141; Yermolaeva, 2012: 189). Thus, based on the tendency of the hole to shift to the center of the psalm, the loss of the middle hole and the appearance of two-hole psalms, the evolution of the bronze psalms proceeded in a functionally primitive direction.

In 1988-90 the Semipalatinsk archaeological expedition of Kemerovo State University, in accordance with the work plan of the scientific cooperation agreement between IAIA and KemSU, conducted archaeological research in the Novoshulba, Borodulikha and Beskaragai districts of East Kazakhstan. Among the interesting burials is a single mound, Kondratievka-21, in which elements of horse harness of the Early Scythian time were found, which gave new material on the burial rite and device of the horse harness of that time. The complex of bronze bridle accessories consisted of gag-bits with stirrup ends with heavily worn inner rings, worn with outer ends on the processes of the U-shaped psalms. Of undoubted interest are large fragments of buckle belts. The authors find analogies to things from Mashenka-1 and Gilevo-10. The monument is dated to the end of the 7 th -6 th centuries. BC (Alekhin, Shulga, 2003: 62-70).

In the period from 1992 to 1998 in the areas of the Upper Irtysh area archaeological works were carried out under the direction of A.A. Tkachev, organized by the East Kazakhstan State University, together with the labor camp of local lore of Ust-Kamenogorsk and Leninogorsk. In the study of funerary monuments in the territory of the Upper Irtysh, four types of tombstone structures were distinguished, which existed throughout the Scythian era: 1) large «royal» mounds with a diameter of 20-50 m, a height of $1.5-3.5 \mathrm{~m}$, surrounded by a moat up to $3-7 \mathrm{~m}$ wide, up to $0.3-0.5 \mathrm{~m}$ deep; 2) round or oval embankments with a diameter of 10-15 m, height $0.5-0.9$ $\mathrm{m}$; 3) flat rounded or oval mounds with a diameter of 6-10 m, height of $0.1-0.3 \mathrm{~m}$; 4) fences without round or oval mounds. Interestingly, in the two excavated fences (Menovoe IV burial grounds, fence 29 and Gerasimovka, fence 22) of the fourth group, sets of horse bridles of the early Scythian time were found (Tkachev, Tkacheva, 1999: 141-142; Shulga, 2008: 244). Gag-bits are two-part, with staggered endings of links, without an additional hole. Psalms with T-shaped pegs, arcuate shape, and a rod rounded in cross section. At the ends are oval holes in the burials of VII - VI centuries BC. Noteworthy is the mutual encounter of both types of stapes holes with an additional hole and without it. They are used with three-horny, bronze psalms of various forms. Thus, the monument can be dated to the middle of VII BC.
In 2005, during the earthworks in the northern part of the village Gerasimovka were found parts of horse harness. All things, along with photos, were transferred to the secondary school teacher E. Sansyzbayev to the East Kazakhstan Regional Museum of History and Local Lore (Ust-Kamenogorsk). In 2016, these details of the horse harness of the Early Saka time were published by the author in the coauthorship of E.M. Kariyev (Besetayev, Kariyev, 2016: 72-78).

In the territory of Kazakhstan, according to K.A. Akishev, the first prototypes of gag-bits and psalms appeared together, or at least shortly after the start of the process of taming the horse (Akishev, 1973: 53). Findings of horse harness items of the 9 th -3 rd centuries $\mathrm{BC}$ indicate the search for the best ways to control a horse and its corresponding functional optimization. In this case, it should be noted significant works N.A. Bokovenko, who in turn complements the one developed by M.K. Kadyrbaev scheme for the evolution of the development and transformation of horse harness (Bokovenko, 1981: 55-57; Bokovenko, 1986). Later, in the late 90s, an article by L.S. Marsadolov, in which the author describes in detail the morphological characteristics of the changes in the forms of gag-bits and psalms of the Altai in the Early Scythian period (Marsadolov, 1998: 5-24). Speaking about the evolution of horse harness in East Kazakhstan, we should note the transition from the early Saka to Pazyryk time (Besetayev, 2015: 25-26). However, the evolution and transformation of horse harness in Saka-Scythian time remains relevant.

The further study and analysis of horse harness of Saka-Scythian time was continued by L.T. Yablonsky, together with M.A. Itina. The authors analyze the details originating from the 22 graves of South Tagisken, suggesting a more detailed classification. Exploring the monuments of this region, and comparing them with the Savromat-Sarmatian world, they note that horse harness is the most characteristic category of funerary harness (Itina, Yablonsky, 1997: 54-62). Later, L.T. Yablonsky in his article «The animal style of the early pastoralists of Aral region in the chronological aspect» identifies two chronological horizons of the Saka cultures of the Aral region (Yablonsky, 1998: 76).

In 2009, work was resumed at Meyemer-2, close to Soldatov, Katonkaragay district of East Kazakhstan. At that time, two mounds of the Early Scythian time were investigated, which were located in the same chain consisting of five mounds stretched along the north-south line. In the second barrow with a diameter of $16 \mathrm{~m}$, height of $0.6 \mathrm{~m}$, elements 
of horse harness were recorded. In the area of the head and neck found the remains of bronze products, representing the decoration of a horse. The horse was wedged in with bronze stirrup bits with pawn holes. Psalms are arcuate, flattened; the back side is flat, on the front side there is a longitudinal groove, with a protruding peg.

Ending psalms have stylized endings in the form of an eagle gryphon's head. Instead of holes at the edges of the psalms, protrusions are arranged in the form of a semi-oval frame.

Among the elements of harness recorded a bronze clasp of the chin strap, bridle dispensers with four holes, piercing of the bridle strap, and wrinkles of the joint belt. All of them were located on the head and under the head of the animal. Under the lower jaw, the bristling block is fixed with a stylized ring, with a flame-shaped or tuft with a protrusion (Samashev, et al., 2010).

Remarkable finds found in the past two decades in the frozen mounds of the Berel cemetery made it possible in detail to restore several versions of horse harness from the 6 th -3 rd centuries $\mathrm{BC}$. Among the many things (№№ 10, 11, 36 kurgans), which have come down to us in relatively good condition, there are excellent samples of horse harness, made in the artistic animal style. All images, taking into account the individual characteristics of the performance, transmit a certain graphic canon. Despite the fact that all the mounds of the Berel burial ground were robbed in antiquity, horse harness remained in good condition (Samashev, 2011; Samashev, Jumabekova, Bazarbaeva, 2010: 251).

Returning to the question of the transitional stage, one should note the finds from the Karakaba treasure, published in 2014. In the fence No. 2, the third kurgan group, bronze details of a horse harness and an iron knife are recorded (Samashev, et al., 2014: 210-211).

A great contribution to the study of riding horse harness was made by P.I. Shulga. In his writings, relying on new and early studied materials, in search of the synchronization of the monuments of early nomads, offers a more detailed classification and typology of items to the harness of a riding horse. Also, they highlighted the general characteristics of the military belt and horse harness of the early Scythian time (Shulga, 2008; Shulga, 2015; Shulga, 2016).

The most interesting materials of recent years are found in the publications of A.Z. Beysenov.
The author, on the basis of materials from Central Kazakhstan, analyzes items of horse harness from Saki time, using the trasological method, and addresses issues of chronology and cultural attribution (Beisenov, 2015: 114-115; Beisenov, Shablavina, 2015: 106-110).

The recently published works of A.D. Tairov [Tairov, 2017] and N.A. Bokovenko [2018] characterize the formation, formation, and main stages of the nomadic cultures of the steppe and mountainsteppe regions of Kazakhstan, based on the extensive material have a more analytical aspect.

\section{Conclusion}

In conclusion, it is worth noting that in almost all the burial grounds of the classical Pazyryk type (Berel, Katon, Kurtu V, Kyzyl-Tu, Kondratievka I, Karakaba) horse harness is basically the same type, they have a bridle set that includes joint, forehead and muzzle belts, decorated with various pendants made in the form of zoomorphic images. Judging by the wealth and sophistication of the images presented in the decorations of horse harness, its semantics is not simplified, but becomes more diverse and rich. The bits are mostly made of iron, with large outer rings, rarely bronze. Psalms are duplex, made mostly of wood or bone (horns). However, the basic functional principles of equipping horse harness are preserved. Saddle horse was made on the left side. The saddle complex was a pillow full of wool or grass, covered with a red cloth, often decorated with applications of various creatures. The design features are similar to those of the Pazyryk saddles of the classical type: they were fastened with the help of breast and under tail tails and one cinch that was fastened with a horn buckle with a hook or a simple knot.

To date, in the steppe and mountain valleys of Kazakhstan, a large number of horse harness items belonging to the VIII-III centuries have been found $\mathrm{BC}$, however, is worth noting that chronologically and territorially represented unevenly. However, many details fall into the category of unpublished «random finds». The introduction of these materials into scientific circulation is a matter of paramount importance, which maintains at the proper level the modern historiography level of archeology.

Further study and typological analysis of horse harness will help to solve general and specific problems of the archeology of the Saco-Scythian time will give impetus to new research. 


\section{References}

Akishev K.A. (1973) Saki aziatskie i skify evropeiskie (obshchee i osobennoe v kul'ture) [Saka Asian and Scythians European (the general and special in culture)]. Arkheologicheskie issledovaniya v Kazakhstane [Archaeological researches in Kazakhstan]. Alma-Ata, Science the Kazakh Soviet Socialist Republic Publ., 1973, pp. 43-58.

Akishev K.A., Akishev A.K. (1978) Problema khronologii rannego etapa sakskoi kul'tury [The problem of the chronology of the early stage of the Saka culture]. Arkheologicheskie pamyatniki Kazakhstana [Archaeological monuments of Kazakhstan]. AlmaAta, Science the Kazakh Soviet Socialist Republic Publ., 1978, pp. 38-63.

Alekhin Yu.P., Shul'ga P.I. (2003) Kurgan Kondrat'evka XXI - novyi pamyatnik ranneskifskogo vremeni na Rudnom Altae [Kurgan Kondratevka XXI - a new monument of the early Scythian epoch in Rudnyi Altai]. Drevnosti Altaya. [Antiquities of Altai]. Gorno-Altaisk, 2003, no 10, pp. 62-70.

Arslanova F.Kh. (1972) Novye materialy VII-VI vv. do n.e. iz Vostochnogo Kazakhstana [New data of VII-VI centuries BC from Eastern Kazakhstan]. Sovetskaya arkheologiya [Soviet archaeology]. Moskow, Science Publ., 1972, no 1, pp. $253-258$.

Arslanova F.Kh. (1981) Sluchainaya nakhodka bronzovykh veshchei v Semipalatinskom Priirtysh'e [Accidental findings of bronze items in Priirtyshe of Semipalatinsk]. Kratkie soobshsheniya instituta arkheologii [Short messages of institute of archeology]. Moskow, Science Publ., 1981, no 163, pp. 54-58.

Beisenov A.Z. (2015) Pamyatniki verkhov'ev reki Atasu v Tsentral'nom Kazakhstane [Monuments of the upper reaches of the Atasu River in Central Kazakhstan]. Vestnik Tomskogo gosudarstvennogo universiteta [Bulletin of Tomsk State University]. Series: History, 2015, vol. 35, no 3, pp. 111-122.

Beisenov A.Z., Shablavina E.A. (2015) Osobennosti lit'ya predmetov konskogo snaryazheniya tasmolinskoi kul'tury [Features of casting items of horse harness Tasmola culture]. Vestnik Tomskogo gosudarstvennogo universiteta [Bulletin of Tomsk State University]. Series: History, 2015, vol. 36, no 4, pp. 105-112.

Besetayev B.B. (2015) Nekotorye voprosy evolyutsii konskogo snaryazheniya skipho-sakskogo vremeni Vostochnogo Kazakhstana [Some issues of horse harness evolution in Scythian-Saka period of Eastern Kazakhstan]. Vestnik Novosibirskogo gosudarstvennogo universiteta [Bulletin of Novosibirsk State University]. Series: History, Philology, 2015, vol. 14, no. 7: Archeology and Ethnography, pp. 24-29.

Besetayev B.B., Kariyev E.M. (2016) Novye materialy po konskomu snaryazheniyu rannesakskogo vremeni iz Vostochnogo Kazakhstana [New Evidence on the Early Saka Horse Harness from Eastern Kazakhstan]. Arkheologiya, etnologiya i antropologiya Evrazii [Archaeology, Ethnology \& Anthropology of Eurasia]. Novosibirsk, Institute of Archaeology and Ethnography of the Siberian Branch of the Russian Academy of Sciences, 2016, vol. 44, no 3, pp. 72-78.

Bokovenko N.A. (1981) Dinamika razvitiya konskoi sbrui v skifskoe vremya na Altae (k probleme tsiklichnosti innovatsii) [Dynamics of development of a horse harness in Scythian epoch in Altai (the problem of recurrence of an innovation)]. Preemstvennost' i innovatsii v razvitii drevnikh kul'tur [Continuity and innovations in development of ancient cultures]. Leningrad, Science Publ., 1981, pp. 55-57.

Bokovenko N.A. (1986) Nachal'nyi etap kul'tury rannikh kochevnikov Sayano-Altaya (po materialam konskogo snaryazheniya) Avtoref. diss. kand. istor. nauk [The initial stage of the culture of early nomads Sayano-Altay (based on horse harness)]. Leningrad, 1986, $24 \mathrm{p}$.

Bokovenko N.A. Phormirovanie konskogo snaryazheniya rannikh kochevnikov Tsentral'noi Azii [The formation of horse harness of the early nomads of Central Asia]. Mir Bol'shogo Altaya [World of Great Altay]. Ust'-Kamenogorsk, 2017, no. 3 (4), pp. $8-42$.

Vishnevskaya O.A., Itina M.A. (1971) Rannie saki Priaral'ya [Early Saka of the Aral Sea region]. Materialy issledovaniya po arkheologii: Problemy skiphskoi arkheologii [Materials of the study on archeology: Problems of Scythian Archeology], no 177. Moskow, Science Publ., 1971, pp. 197-208.

Vishnevskaya O.A. (1973) Kul'tura sakskikh plemen nizov'ev Syrdar'i v VII-V vv. do n.e. [Culture of the Saka tribes of the lower Syrdarya in the VII-V centuries BC]. Trudy Khorezmskoi arkheologo-etnographicheskoi ekspeditsii [Proceedings of the Khorezm archaeological and ethnographic expedition], no 8. Edited by S.P. Tolstov. Moskow, Science Publ., 1973,160 p.

Gorbunova N.G. (2001) Konskaya upryazh' rannikh sakov Tsentral'noi Azii (Srednyaya Azia i Kazakhstan, krome Zapadnogo) [Horse trappings of early juice of Central Asia (Central Asia and Kazakhstan, except Western)]. Drevnie tsivilizatsii Evrazii. Istoriya i kultura [Ancient civilizations of Eurasia. History and culture]. Moscow, Vostochnaya literatura [Eastern Literature] Publ., 2001, pp. 179-200.

Gryaznov M.P. (1947) Pamyatniki maiemirskogo etapa epokhi rannikh kochevnikov na Altae (Doklad na sektore bronzy i rannego zheleza Instituta istorii material'noi kul'tury: 5. VII. 1945) [Monuments mayemirskii stage epoch of early nomads in Altay]. Kratkie soobshsheniya instituta istorii material'noi kul'tury [Short messages of institute of history and material culture]. MoskowLeningrad, 1947, no 18, pp. 9-17.

Gryaznov M.P., Mannai-ool M.Kh. (1973) Raskopki kurgana Arzhan v Tuve [Excavations Arzhan mound in Tuva]. Arkheologicheskie otkrytiya 1972 goda [Archaeological Discoveries of 1972]. Moskow, 1973, pp. 207-209. 
Gryaznov M.P. (1980) Arzhan. Tsarskii kurgan ranneskifskogo vremeni [Arzhan. Royal mound of early Scythian era]. Leningrad: Science Publ., 1980, 60 p.

Ermolaeva A.S. (1987) Pamyatniki perekhodnogo perioda ot bronzy k rannemu zhelezu [Monuments transition from the Bronze Age to the early iron]. Arkheologicheskie pamyatniki v zone zatopleniya Shul'binskoi hydroelectric power stations [Archaeological monuments in a zone of flooding of Shulbinsk hydroelectric power station]. Alma-Ata, Science the Kazakh Soviet Socialist Republic Publ., 1987, pp. 135-141.

Ermolaeva A.S. (2012) Pamyatniki predgornoi zony Kazakhskogo Altaya (epokha bronzy - rannee zhelezo) [Monuments foothill zone of Kazakh Altay (Bronze Age - Early Iron)]. Almaty, Institute of Archeology named after A.Kh. Margulana Publ., 2012. $238 \mathrm{p}$.

Itina M.A., Yablonskii L.T. (1997) Saki Nizhnei Syrdar'i (po materialam mogil’nika Yuzhnyi Tagisken) [Saka of the Lower Syrdarya (based on the materials of the South Tagisken cemetery)]. Moskow, Russian Political Encyclopedia Publ., 1997. 187 p.

Kadyrbaev M.K. (1966) Pamyatniki tasmolinskoi kul'tury [Monuments of Tasmola culture] Drevnyaya kul'tura Tsentral'nogo Kazakhstana [Ancient culture of Central Kazakhstan]. Alma-Ata: Science the Kazakh Soviet Socialist Republic Publ., 1966, pp. 303-433.

Kadyrbaev M.K. (1968) Nekotorye itogi i perspektivy izucheniya arkheologii rannezheleznogo veka Kazakhstana [Some results and prospects of studying of archaeology of the early Iron Age of Kazakhstan]. Novoe v arkheologii Kazakhstana [New in archaeology of Kazakhstan]. Alma-Ata, Science the Kazakh Soviet Socialist Republic Publ., 1968, pp. 21-36.

Marsadolov L.S. (1998) Osnovnye tendentsii v izmenenii form udil i psaliev i pryazhek konya na Altae v VIII-V vv. do n.e. [Major trends in forms of mouthpiece, Psalm and buckles horse in Altay VIII-V centuries BC]. Snaryazhenie verkhovogo konya na Altae v rannem zheleznom veke i srednevekov'e [Harness of a riding horse in Altai in the early Iron Age and the Middle Ages]. Barnaul, Altai State University Publ., 1998, pp. 5-24.

Ol'khovskii V.S. (1997) Skiphskaya triada [The Scythian Triad]. Materialy issledovaniya po arkheologii Rossii: Pamyatniki predskiphskogo i skiphskogo vremeni na yuge Vostochnoi Evtopy [Materials of the research on archeology of Russia: Monuments of the early Scythian and Scythian times in the south of Eastern Europe]. 1997, no 1, pp. 85-96.

Rudenko S.I. (1953) Kul'tura naseleniya Gornogo Altaya v skifskoe vremya [Culture of the population in the mountainous Altay in Scythian epoch]. Moskow-Leningrad, Academy of Sciences of the Union of Soviet Socialist Republics Publ., 1953,402 p.

Rudenko S.I. (1960) Kul'tura naseleniya Tsentral'nogo Altaya v skifsoe vremya [Culture of the population of the Central Altay in Scythian epoch]. Moskow-Leningrad, Academy of Sciences of the Union of Soviet Socialist Republics Publ., 1960,360 p. and 78 tables.

Samashev Z., Dzhumabekova G.S., Bazarbaeva G.A., Besetaev B.B., Alzhanov K.K., Zhuniskhanov A.S., Tolegenov E.T., Chotbaev A.E. (2010) Promezhutochnyi otchet o nauchno-issledovatel'soi rabote. Gosudarstvennaya programma «Kul'turnoe nasledie» po teme «Berel» [Interim report on the research work. The state program «Cultural Heritage» on «Berel»]. Almaty, Institute of Archeology named after A.Kh. Margulana Publ., 2010, 62 p.

Samashev Z., Dzhumabekova G.S., Bazarbaeva G.A. (2010) Konskoe snaryazhenie drevnikh skotovodov Altaya: opyt rekonstruktsii (po materialam kurgana № 10 mogil'nika Berel) [Horse harness of ancient cattle-farmers of Altai: experience of reconstruction (on burial ground barrow materials Berel)]. Arkheologicheskii al'manakh. Izobrazitel'noe iskusstvo v arkheologicheskom nasledii [Archaeological almanac. The fine arts in archaeological heritage], Donetsk, Lebed' [Swan] Publ., 2010, no. 21, pp. 251-286.

Samashev Z. Berel [Berel]. Almaty, Taimas Publ., 2011, 236 p.

Samashev Z., Chotbaev A., Zhalmagambetov Zh., Kariev E., Aitkali A., Akhmetov M. (2014) Karakaba: pervye rezul'taty issledovanii [Karakaba: first results of research]. Trudy Philiala Instituta arkheologii: Kul'turno-istoricheskie protsessy v Kazakhstansikh stepyakh v drevnosti i srednevekov'e: traditsii i novatsii [Proceedings of the Branch of the Institute of Archeology: Cultural and historical processes in the Kazakh steppes in antiquity and the Middle Ages: traditions and innovations]. Astana, Publishing group of the Branch of the Institute of Archeology named after A.Kh. Margulan in Astana, 2014, pp. 207-236.

Sorokin S.S. (1962) Dosledovanie Bol'shogo Berel'skogo kurgana [Further investigation of the Big Berel mound]. Soobshsheniya Gosudarstvennogo Ermitazha [Messages of the State Hermitage]. Leningrad, 1962, no 23, pp. 70-72.

Sorokin S.S. (1966) Pamyatniki rannikh kochevnikov v verkhov'yakh Bukhtarmy [Monuments of early nomads in the upper Buhtarma]. Arkheologicheskii sbornik [Archaeological collection]. Moskow-Leningrad, Sovetskii khudozhnik [Soviet artist] Publ., 1966, no 8, pp. 39-60.

Tairov A.D. Rannie kochevniki Zhaiyk-Irtyshskogo mezhdurech'ya v VIII-VI vv. do n.e. [Early nomads of the Zhaiyk-Irtysh interfluve in VIII-VI cc. BC]. Astana, Kazakh science research institute of culture Publ., 392 p.

Tkachev A.A., Tkacheva N.A. (1999) Itogi issledovaniya arkheologicheskikh pamyatnikov Ust'-Kamenogorskogo mikroraiona (1994-1998 гг.) [Results of the study of archaeological sites of Ust-Kamenogorsk district (1994-1998 years)]. Vestnik arkheologii, antropologii i etnografii [Messenger of archeology, anthropology and ethnography]. Tyumen', 1999, no 2, pp. 136-145.

Chernikov S.S. (1968) Nekotorye zakonomernosti istoricheskogo razvitiya rannikh kochevnikov (po arkheologicheskim materialam Zapadnogo Altaya) [Some regularities of the historical development of early nomads (according to archaeological materials of Western Altay )]. Tezisy dokladov i soobshchenii sovetsikh uchenykh: mezhd. konf. po istorii, arkheologii i kul'ture Tsentral'noi 
Azii v Kushanskuyu epokhu [Theses of reports and message of the Soviet scientists: the international conference on history, archeology and culture of Central Asia during the Kushansky era]. Dushanbe, 1968, pp. 62-64.

Chlenova N.L. (1967) Proiskhozhdenie i ranyaya istoriya plemen Tagarskoi kul'tury [The origin and early history of the tribes of the Tagar culture]. Moskow, Science Publ., 1967, 300 p.

Shul'ga P.I. (2008) Snaryazhenie verkhovoi loshadi i voinskie poyasa na Altae. Ch. I: Ranneskifskoe vremya [Saddle horse harness and military zones in the Altay. Part I: Early Scythian Time]. Barnaul, Azbuka [ABC] Publ., 2008, 276 p.

Shul'ga P.I. (2015) Snaryazhenie verkhovoi loshadi v Gornom Altae i Verkhnem Priob'e Ch. II: (VI-III vv. do n.e.) [Equestrian harness in the Altai Mountains and Upper Ob River. Part II: (VI-III centuries BC)]. Novosibirsk, Editorial and Publishing Center of Novosibirsk State University, 2015. 322 p.

Shul'ga P.I. (2016) Mogil'nik ranneskiphskogo vremeni Gilevo-10 v predgor'yakh Altaya [Imperial Era of Early Scythian Time Gilyovo-10 in the foothills of Altai]. Novosibirsk, Publishing Polygraphic Center of Novosibirsk State University, 2016. 258 p.

Yablonskii L.T. (1998) Zverinyi stil' rannikh skotovodov Priaral'ya v khronologicheskom aspekte [Animal style of the early pastoralists of the Aral Sea in the chronological aspect]. Skiphy, Khazary, Slavyane, Drevnyaya Rus' [Scythians. The Khazars. Slavs. Ancient Russia]. Sankt-Peterburg: State Hermitage Publ., 1998, pp. 73-76. 